\title{
Penyaluran Dana Bank Syariah Melalui Pembiayaan Murabahah, Istishna', dan Ijarah Sebelum dan Selama Pandemi Covid 19
}

\author{
Taudlikhul Afkar ${ }^{* *}$, Teguh Purwanto ${ }^{2)}$ \\ ${ }^{1,2}$ Fakultas Ekonomi dan Bisnis, Universitas PGRI Adi Buana Surabaya \\ *Email korespondensi: afkar@unipasby.ac.id
}

Impact of the Covid-19 pandemic in Indonesia is not only in the productive sector but has an impact on the financial sector such as conventional and Islamic financial institutions including banking. Islamic banks have business activities through murabaha, istisna', and ijara financing for sale and purchase and lease types. The impact felt by the banking sector can be seen from the existence of financing problems. The purpose of this research is to compare the conditions of sharia financing before and during the Covid-19 pandemic. The method used is the paired sample t-test with a sample of Islamic banks in Indonesia. The results show murabaha and istisna' financing has increased, while ijara financing has decreased during the Covid-19 pandemic.

Keywords : financing, murabaha, istisna', ijara, covid-19 pandemic, Islamic banks

Saran sitasi: Afkar, T., \& Purwanto, T. (2021). Penyaluran Dana Bank Syariah Melalui Pembiayaan Murabahah, Istishna', dan Ijarah Sebelum dan Selama Pandemi Covid 19. Jurnal Ilmiah Ekonomi Islam, 7(02), 900-907. doi:http://dx.doi.org/10.29040/jiei.v7i2.2423

DOI: http://dx.doi.org/10.29040/jiei.v7i2.2423

\section{PENDAHULUAN}

Penyaluran dana melalui pembiayaan merupakan salah satu kegiatan usaha paling besar dari lembaga keuangan terutama perbankan. Lembaga keuangan syariah yang cenderung bergerak di sektor produktif juga tidak lepas dari penyaluran pembiayaan karena adanya persaingan kompetitif dari tiap lembaga keuangan (Ascarya \& Yumanita, 2008). Meskipun demikian bank Syariah dalam menyalurkan pembiayaan tetap memperhatikan kemaslahatan untuk umat melalui maqashid syariah tentunya dengan keadilan (Herlyanto \& Oktavendi, 2019). Pembiayaan yang paling besar dilakukan oleh bank syariah dan diminati oleh masyarakat atau nasabah adalah pada pembiayaan murabahah sedangkan pembiayaan salam tidak banyak diminati bahkan hampir tidak ada yang menggunakan pembiayaan tersebut (Iskandar, 2016). Kondisi seperti itu mungkin karena dalam situasi keuangan normal, namun akhir-akhir ini terjadi pandemi covid-19 yang memberikan dampak luas pada sektor-sektor produktif maupun keuangan sehingga menimbulkan pemikiran tetang kondisi penyaluran pembiayaan kepada nasabah dan sebaliknya bagaimana tingkat pengembalian pembiayaan dari para nasabah yang tentunya terdampak covid-19 saat ini. Tentunya permasalahan tersebut menjadi pertanyaan yang tujuannya untuk melihat kemampuan tingkat penyaluran pembiayaan bank syariah sebelum dan selama pandemi covid-19.

Kondisi selama pandemi covid-19 banyak sektor usaha yang terdampak tidak terkecuali sektor perbankan dengan adanya pembiayaan bermasalah sehingga sektor ekonomi melemah (Hanoatubun, 2020), hal ini ditandai dengan adanya pengangguran dan kemiskinan semakin bertambah di negara yang terdampak (Arianto, 2021). Tentunya banyaknya pengangguran karena terdampak covid-19 ini dapat menyebabkan kemampuan seseorang untuk membayar kewajibannya jika memiliki pinjaman di lembaga keuangan seperti bank syariah. Seperti yang dapat digambarkan bahwa pembiayaan bermasalah memperlambat bank Syariah untuk mendapatkan laba (Afkar \& Fauziyah, 2021), terlihat juga pada pembiayaan bagi-hasil yang dilakukan bank syariah (Afkar, 2018). Hal ini mungkin terjadi karena transaksi yang dilakukan adalah lebih banyak pada bagi hasil, kemudian permasalahan yang menjadi pertanyaan berikutnya adalah bagaimana dengan jenis 
pembiayaan non bagi-hasil seperti murabahah, ijarah, dan istishna' yang sebenarnya memberikan kepastian dalam pembayaran melalui margin pendapatan.

Murabahah merupakan transaksi jual beli barang yang dapat dilakukan secara cicilan dengan perolehan margin dari selisih harga jual dan harga beli dimana penjual berkewajiban memberikan informasi harga perolehan barang yang dijual (Karim, 2010). Transaksi pembiayaan yang dilakukan melalui murabahah menjadi salah satu alternatif yang dilakukan sesuai dengan karakteristik orang Indonesia yang cenderung konsumtif. Istishna' merupakan transaksi jual beli barang dengan cara pesanan khusus, dimana pembeli memberikan spesifikasi jenis barang yang diinginkan kemudian penjual mengerjakan pesanan tersebut (Nurhayati \& Wasilah, 2015). Istishna' memang bukan jenis pembiayaan yang dominan di Indonesia namun tetap masih diminati (Iskandar, 2016).

Pembiayaan Syariah lainnya yaitu ijarah masih memberikan kontribusi dalam pembiayaan syariah, dimana ijarah merupakan pembiayaan untuk sewa guna barang dengan pembayaran ujrah atau sewa. Ijarah merupakan akad perpindahan manfaat atas suatu barang atau jasa dalam waktu tertentu dengan model pembayaran upah atau sewa yang tidak diikuti dengan kepemilikan barang tersebut. Artinya Ijarah hanya ini hanya mengambil manfaat suatu barang atau jasa dengan penggantian secara finansial berupa upah atau sewa dalam jumlah tertentu (Nurhayati \& Wasilah, 2015). Namun jika akad Ijarah ini diakhiri dengan kepemilikan maka akad sudah berbeda yaitu menjadi Ijarah Muntahiya bit Tamlik. Pada dasarnya dalam ijarah terdapat ijarah muntahiya bit tamlik (IMBT) yang merupakan perpaduan jual-beli dan sewa (Santoso \& Anik, 2017).

Sudut pandang teori pertukaran dalam traksaksi pembiayaan syariah menunjukkan adanya pertukaran yang dilakukan dengan cara tukar menukar uang maupun asset, yang dapat diterjemahkan melalui pertukaran asset dengan asset, pertukaran aset dengan uang, dan pertukaran uang dengan uang (Karim, 2010). Konsep dalam teori pertukaran ini memberikan gambaran mengenai pertukaran yang terjadi dalam suatu traksaski pembiayaan syariah yang dilakukan bank syariah. Transaksi yang dapat terjadi yaitu seperti transaksi jual-beli barang maupun sewamenyewa barang.

Penilaian bank syariah sebelum terjadi krisis dalam pandemi covid-19 menunjukkan kinerja yang baik yang diukur melalui maslaha efficient quadrant (MEQ) (Rusydiana \& Sanrego, 2018). Kondisi seperti ini didukung oleh (Afkar, 2015a) yang menjelaskan bahwa bank syariah masih memiliki daya tahan yang baik ketika terjadi krisis keuangan global. Tentunya berbagai krisis keuangan telah dilalui bank syariah sejak berdiri di Indonesia dan belum ada satupun bank sayriah yang mengalami likudiasi atau kebangkrutan. Salah satu contoh yang dilakukan bank syariah masih tetap memberikan pelayanan kepada usaha mikro kecil dan menengah dari segi pembiayaan (Tubastuvi, 2018). Hal ini dapat memberikan kemungkinan adanya risiko pembiayaan ketika dilakukan pada saat situasi pandemi covid-19 saat ini, seperti penjelasan (Said et al., 2019) yang mengatakan bahwa perlunya identifikasi risiko yang ditimbulkan dari pembiayaan syariah dengan cara mengukur melalui tingkat kemaslahatan.

Permasalahan yang dihadapi bisnis dan lembaga keuangan saat ini adalah bagaimana caranya tetap memberikan pelayanan kepada konsumen maupun nasabah melalui penyediaan pembiayaan dengan tetap mendapatkan keuntungan sebagai salah satu bentuk menjaga kontinyuitas entitas usaha yang dikelola. Mungkin dalam bank sayriah untuk pembiayaan murabahah, istishna, dan ijarah tidak termasuk jenis pembiayaan produktif namun dari segi kepastian dalam pendapatannya seharusnya memberikan kontribusi yang positif untuk pertumbuhan laba bank Syariah dan nilai perusahaan. Namun, dalam situasi yang tidak menentu secara ekonomi dan keuangan global ini menuntut pemikiran yang logis dan sistematis. Oleh karena itu penelitian ini mencoba mengkaji penyaluran dana bank Syariah melalui pembiayaan murabahah, istishna', dan ijarah dalam situasi pandemi covid-19 saat ini. Tujuannya adalah untuk melihat perbadingan kemampuan bank syariah selama memberikan pembiayaan sebelum dan selama pandemi covid-19.

\section{Pengembangan Hipotesis}

Transaksi jual-beli barang yang terjadi dapat dilakukan dengan cara pembeli menyediakan barang yang dijual kemudian pembeli membayar dengan sejumlah uang sesuai dengan harganya. Hal ini menunjukkan bahwa telah terjadi tukar-menukar uang dan barang dengan jumlah yang sesuai dimana dapat dilakukan pula dengan menukar jenis barang namun kedua belah pihak harus saling sepakat agar tidak terjadi kedzoliman (Afkar, 2015b). Murabahah merupakan transaksi penjualan barang yang 
menyatakan harga perolehan dan margin keuntungan yang disepakati oleh pihak-pihak yang terlibat transaksi (Nurhayati dan wasilah, 2015). Pembiayaan Murabahah merupakan akad pembiayaan mengenai jual-beli barang dengan menyatakan harga perolehan dan keuntungan (margin) yang disepakati antara penjual dan pembeli (Karim, 2010). Transaksi pembiayaan murabahah memberikan kontribusi yang paling dominan dibandingkan dengan jenis pembiayaan lainnya (Iskandar, 2016). Dampak covid19 di Indonesia memberikan gambaran penurunan ekonomi secara nasional dan perbankan (Hanoatubun, 2020), dan juga pada nilai rupiah yang menurun sehingga dapat mengakibatkan kemampuan keuangan (Hadiwardoyo, 2020).

\section{Hipotesis 1:Pembiayaan murabahah' mengalami} penurunan selama pandemi covid-19

Peran perbankan di sektor riil menjadi salah satu bentuk kegiatan bank Syariah dalam membantu perekonomian secara nasional (Hasyim, 2016). Selain sektor riil, terdapat produk pembiayaan yang memberikan sarana kepada nasabah untuk memenuhi kebutuhan dengan pembiayaan Istishna' yang merupakan akad pembiayaan jual beli dalam bentuk pemesanan barang sesuai keinginan pembeli atau bersifat tertentu yang disepakati oleh penjual dan pembeli (Karim, 2010). Pembiayaan istishna' dalam bank syariah memiliki pengaruh untuk memperoleh tingkat profitabilitas (Sari \& Anshori, 2018). Selain itu pembiayaan istishna' juga memiliki kontribusi memberikan peluang memperoleh laba bagi bank Syariah (Iskandar, 2016), namun seiring peran pembiayaan istishna' tersebut kedalam perolehan laba, prediksi yang dilakukan (Afkar \& Fauziyah, 2021) menunjukkan kemampuan bank syariah memperoleh laba yang semakin menurun selama terjadi pandemi covid-19 terutama pada tahun 2021 .

\section{Hipotesis 2: Pembiayaan Istishna' mengalami} penurunan selama pandemi covid-19

Pembiayaan Ijarah merupakan akad pembiayaan degan cara pemindahan hak guna atau manfaat atas suatu barang atau jasa dalam waktu tertentu melalui pembayaran sewa atau upah, tanpa diikuti dengan pemindahan kepemilikan barang itu sendiri (Fatwa DSN No.9). Dalam akad Ijarah pembayaran sewa dapat dilakukan dimuka maupun di belakang, ataupun dengan angsuran sesuai dengan kesepakatan antara pemberi sewa dengan penyewa. Sama seperti akad Murabahah dan Istishna, apabila terjadi penundaan pembayaran yang disebabkan karena kelalaian penyewa maka dapat dikenakan kifarat (denda). Salah satu risiko yang dapat terjadi dalam pembiayaan Ijarah ini adalah gagal bayar dari yang menyewa. Dalam PSAK 107 menyebutkan untuk mengurangi risiko kerugian atau hal-hal yang tidak diinginkan, maka pemilik aset atau pemberi sewa dapat meminta jaminan kepada penyewa atas akad ijarah ini. Hasil penelitian menunjukkan bahwa pendapatan ijarah memiliki pengaruh terhadap profitabilitas bank syariah (Santoso \& Anik, 2017). Selain itu ijarah merupakan salah satu jenis pembiayaan yang memiliki kepastian dalam pembayaran yang dilakukan nasabah (Alfie \& Khanifah, 2018). Namun kondisi ekonomi nasional dan global sedang mengalami krisis akibat pandemi sehingga menyebabkan penuruan kemampuan profitabilitas dari dunia usaha (Arianto, 2021).

\section{Hipotesis 3: Pembiayaan Ijarah mengalami penurunan selama terjadi pandemi covid-19}

\section{METODE PENELITIAN}

Pendekatan penelitian ini menggunakan deskriptif kuantitatif dengan melakukan pengujian perbedaan untuk memperoleh perbandingan hasil. Untuk memperoleh perbadingan tersebut digunakan teknik analisis paired-sample t-test karena dalam penelitian ini menggunakan data 2(dua) sampel dengan fenomena yang berbeda atau 2(dua) sampel berpasangan dengan pengukuran yang berbeda. Sampel dalam penelitian ini adalah bank umum syariah di Indonesia menggunakan teknik sampel jenuh dengan cara mengambil keseluruahan bank syariah di Indonesia sejumlah 14 bank Syariah. Data yang dikumpulkan adalah data laporan gabungan bank umum Syariah yang dilaporkan pada otoritas jasa keuangan dari pembiayaan murabahah, istishna', dan ijarah. Periode data yang dikumpulkan adalah 20192020 dengan asumsi pada tahun 2019 dianggap sebagai data sebelum terjadinya pandemi covid-19, sedangkan tahun 2020 merupakan data selama pandemi covid-19.

\section{HASIL DAN PEMBAHASAN}

\subsection{Hasil Penelitian}

Hasil penelitian ini diawali dengan melakukan uji normalitas data dengan tujuan untuk memastikan data yang digunakan sesuai dengan kebutuhan dan kaidah statistik. Hasil pengujian normalitas ditunjukkan pada tabel 1. 


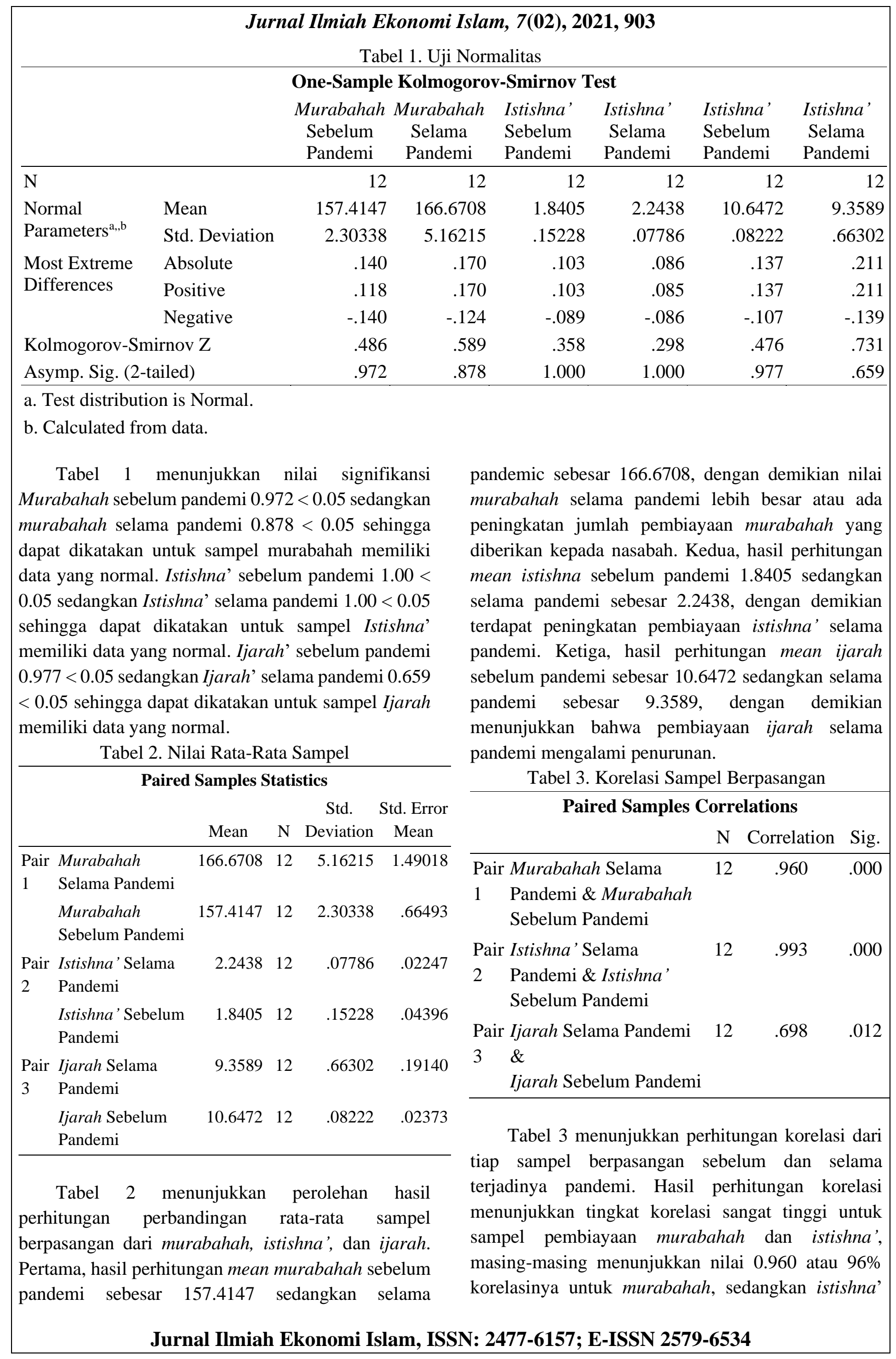


sebear 0.993 atau 99,3\%. Selain itu untuk tingkat korelasi ijarah menunjukkan nilai sebesar 0.698 atau
69,8\% sehingga termasuk kategori korelasi pada tingkat sedang.

Tabel 4. Hasil Uji Perbedaan Sampel

\begin{tabular}{|c|c|c|c|c|c|c|c|c|c|}
\hline \multicolumn{10}{|c|}{ Paired Samples Test } \\
\hline & \multicolumn{9}{|c|}{ Paired Differences } \\
\hline & & \multicolumn{7}{|c|}{$\begin{array}{l}95 \% \text { Confidence } \\
\text { Interval of the } \\
\text { Difference }\end{array}$} & \multirow[b]{2}{*}{$\begin{array}{l}\text { Sig. }(2 \\
\text { tailed) }\end{array}$} \\
\hline & & Mean & $\begin{array}{c}\text { Std. } \\
\text { Deviation }\end{array}$ & $\begin{array}{l}\text { Std. Error } \\
\text { Mean }\end{array}$ & Lower & Upper & $\mathrm{t}$ & $\mathrm{df}$ & \\
\hline $\begin{array}{l}\text { Pair } \\
1\end{array}$ & $\begin{array}{l}\text { Murabahah Selama } \\
\text { Pandemi - Murabahah } \\
\text { Sebelum Pandemi }\end{array}$ & 9.25617 & 3.02007 & .87182 & 7.33731 & 11.17503 & 10.617 & 11 & .000 \\
\hline $\begin{array}{l}\text { Pair } \\
2\end{array}$ & $\begin{array}{l}\text { Istishna' Selama Pandemi } \\
\text { - Istishna' Sebelum } \\
\text { Pandemi }\end{array}$ & .40333 & .07553 & .02180 & .35534 & .45133 & 18.498 & 11 & .000 \\
\hline $\begin{array}{l}\text { Pair } \\
3\end{array}$ & $\begin{array}{l}\text { Ijarah Selama Pandemi - } \\
\text { Ijarah Sebelum Pandemi }\end{array}$ & -1.28825 & 60848 & .17565 & -1.67486 & -.90164 & -7.334 & 11 & .000 \\
\hline
\end{tabular}

\section{Hasil Uji Beda Sampel Pembiayaan Murabahah}

Hasil uji beda sampel pembiayaan murabahah sebelum dan selama pandemi covid-19 ditunjukkan pada tabel 4. Perhitungan yang dilakukan diperoleh dari hasil perhitungan selisih mean sebelum dan selama pandemi sebesar 9.25617. Sedangkan nilai $\mathrm{t}_{\text {hitung }}$ sebesar $10.617>\mathrm{t}_{\text {tabel }}$ sebesar 2.200 , dengan tingkat signifikansi sebesar $0.000<0,05$. Hasil pehitungan tersebut menunjukkan perbedaan penyaluran dana melalui pembiayaan murabahah, dengan demikian situasi selama pandemi covid-19 menunjukkan adanya peningkatan terhadap jumlah rata-rata pembiayaan murabahah yaitu sebanyak 9.25617. Dengan demikian hipotesis yang menyatakan bahwa pembiayaan murabahah selama terjadi pandemi covid-19 mengalami penurunan diterima.

\section{Hasil Uji Beda Sampel Pembiayaan Istishna,}

Hasil uji beda sampel pembiayaan istishna' sebelum dan selama pandemi covid-19 ditunjukkan pada tabel 4. Perhitungan yang dilakukan diperoleh dari hasil perhitungan selisih mean sebelum dan selama pandemi sebesar 0.40333 . Sedangkan nilai $\mathrm{t}_{\text {hitung }}$ sebesar $18.498>\mathrm{t}_{\text {tabel }}$ sebesar 2.200 , dengan tingkat signifikansi sebesar $0.000<0,05$. Hasil pehitungan tersebut menunjukkan perbedaan penyaluran dana melalui pembiayaan istishna', dengan demikian situasi selama pandemi covid-19 menunjukkan adanya peningkatan terhadap jumlah rata-rata pembiayaan istishna' yaitu sebanyak 0.40333. Dengan demikian hipotesis yang menyatakan bahwa pembiayaan istishna' selama terjadi pandemi covid-19 mengalami penurunan diterima.

\section{Hasil Uji Beda Sampel Pembiayaan Ijarah}

Hasil uji beda sampel pembiayaan ijarah sebelum dan selama pandemi covid-19 ditunjukkan pada tabel 4. Perhitungan yang dilakukan diperoleh dari hasil perhitungan selisih mean sebelum dan selama pandemi sebesar -1.28825 . Sedangkan nilai $\mathrm{t}_{\text {hitung }}$ sebesar $-7.334>\mathrm{t}_{\text {tabel }}$ sebesar 2.200 , dengan tingkat signifikansi sebesar $0.000<0,05$. Hasil pehitungan tersebut menunjukkan perbedaan penyaluran melalui pembiayaan ijarah, dengan demikian situasi selama pandemi covid-19 menunjukkan adanya penurunan terhadap jumlah ratarata pembiayaan ijarah yaitu sebanyak -1.28825. Dengan demikian hipotesis yang menyatakan bahwa pembiayaan ijarah selama terjadi pandemi covid-19 mengalami penurunan ditolak.

\subsection{Pembahasan}

Perbedaan Pembiayaan Murabahah Sebelum dan Selama Pandemi Covid-19

Dampak pandemi covid-19 di Indonesia tidak hanya pada sektor bisnis kecil atau UMKM saja namun diseluruh sektor termasuk dunia pendidikan maupun perbankan. Masyarakat banyak yang 


\section{Jurnal Ilmiah Ekonomi Islam, 7(02), 2021, 905}

mengeluh terkait dengan sulitnya memenuhi kebutuhan hidupnya karena adanya larangan untuk berkumpul banyak orang. Sulitnya memenuhi kebutuhan hidup ini dapat berdampak pada kosumsi masyarakat terhadap barang dan jasa terutama untuk transaksi jual-beli. Solusi yang diberikan oleh lembaga keuangan seperti bank syariah adalah memberikan pembiayaan Syariah untuk sektor produktif dan keuangan. Hasil penelitian ini menunjukkan bahwa tingkat pembiayaan murabahah mengalami peningkatan rata-rata jumlah pembiayaan yang diberikan, dengan demikian memberikan gambaran bahwa masyarakat di Indonesia masih memberikan sikap positif terhadap pemenuhan transaksi jual-beli. Kondisi seperti ini didukung oleh penyataan (Iskandar, 2016) yang menjelaskan bahwa murabahah masih mendominasi jenis pembiayaan syariah dibandingkan jenis pembiayaan syariah lainnya.

Hasil penelitian ini selain menunjukkan adanya kemampuan masyarakat di Indonesia untuk melakukan transaksi jual-beli, juga menunjukkan kepercayaan masyarakat terhadap pembiayaan Syariah yang dilakukan bank syariah dengan adanya ukuran tingkat efisiensi dalam pembiayaan dengan adanya kemaslahatan melalui keadilan (Herlyanto \& Oktavendi, 2019). Sudut pandang teori percampuran menunjukkan masyarakat masih mampu dalam melakukan pertukaran aset yang disediakan oleh bank syariah dengan uang yang dimiliki masyarakat terutama yang menjadi nasabah bank Syariah. Mungkin yang perlu didiskusikan dalam penelitian selanjutnya adalah pertanyaan mengapa dalam situasi pandemi covid-19 jumlah pembiayaan bank syariah melalui pembiayaan murabahah semakin meningkat dibandingkan sebelum terjadi pandemi covid-19. Hal ini karena terdapat hasil penelitian yang menunjukkan bahwa dengan Islamic Social Finance mampu meningkatkan pendapatan UMKM selama pandemic covid-19 (Hadiyan et al., 2021), atau mungkin karena pembiayaan murabahah ini merupakan salah satu pembiayaan yang memberikan kepastian pendapatan dari selisih harga jual dengan harga beli sehingga menjadi salah satu pemenuhan kebutuhan masyarakat terkait aset yang diperjualbelikan.

\section{Perbedaan Pembiayaan istishna Sebelum dan Selama Pandemi Covid-19}

Istishna' merupakan salah satu transaksi pembiayaan syariah dari bank syariah yang memberikan kesempatan pada nasabah untuk memiliki asset yang diinginkan dengan jenis dan bentuk yang tidak dijual secara masal, dengan kata lain bersifat kustom. Tentunya pembiayaan jenis ini melibatkan produsen untuk membuat jenis barang yang diinginkan tersebut dan bukan merupakan tanggungjawab bank syariah untuk membuat barang tersebut. Kondisi selama pandemi covid-19 ini menuntut masyarakat berpikir kreatif untuk memperoleh pendapatan dalam rangka memenuhi kebutuhan hidupnya yang mungkin dapat dilakukan dengan menerapkan ekonomi Islam (Nabhan, 2010). Anehnya, hasil penelitian ini menunjukkan bahwa masyarakat di Indonesia selama terjadi pandemi covid-19 masih dapat memenuhi kebutuhan yang termasuk kategori bukan barang pokok melainkan barang yang bersifat pribadi atau kustom. Hal ini ditunjukkan dengan adanya peningkatan jumlah pembiayaan istishna' selama pandemi covid-19 terjadi.

Sudut pandang teori pertukaran dapat ditunjukkan dengan adanya kemauan masyarakat di Indonesia melakukan pertukaran uangnya dengan asset yang ingin dimiliki dalam bentuk yang berbeda atau kustom sesuai keinginannya. Tidak ada yang salah karena setiap orang memiliki keinginan masingmasing, namun yang menjadi pertanyaan adalah ketika situasi pandemi covid-19 ternyata masih banyak masyarakat yang memiliki kemampuan untuk memenuhi kebutuhannya terhadap barang yang bukan produksi masal atau bukan kebutuhan pokok, atau mungkin ini merupakan kondisi yang menjadi peluang bagi produsen-produsen tertentu sebagai peluang bisnis (Rohmah, 2020). Artinya, pembiayaan yang diberikan oleh bank syariah melalui istishna' lebih tinggi selama pandemi dibandingkan sebelum terjadinya pandemi artinya dapat meningkatkan laba yang diperoleh (Sari \& Anshori, 2018). Meskipun demikian prediksi perolehan laba bank syariah selama periode 2021 akan mengalami penurunan terutama pada akhir periode sekitar triwulan terakhir (Afkar \& Fauziyah, 2021).

\section{Perbedaan Pembiayaan Ijarah Sebelum dan Selama Pandemi Covid-19}

Pembiayaan ijarah menjadi salah satu alternatif jenis pembiayaan yang memberikn peluang kepada masyarakat yang ingin menggunakan asset tanpa harus melakukan pembelian asset tersebut. Beberapa hasil penelitian menunjukkan bahwa pembiayaan ijarah berpengaruh terhadap perolehan laba bank syariah seperti (Eprianti \& Adhita, 2017) menjelaskan 


\section{Jurnal Ilmiah Ekonomi Islam, 7(02), 2021, 906}

bahwa pendapatan ijarah memiliki peran terhadap profitabilitas bank syariah. Namun hasil penelitian ini menunjukkan bahwa pembiayaan ijarah mengalami penurunan selama pandemi covid-19 terjadi, hal ini menunjukkan pengaruh signifikan terhadap perolehan laba bank syariah.

Pembiayaan ijarah mungkin tidak menjadi yang dominan dalam penyaluran dana bank syariah namun masih menjadi alternatif dalam penyediaan pembiayaan bagi masyarakat dan juga bagi bank syariah untuk memperoleh pendapatan. Teori percampuran memiliki sudut pandang dalam konsep pembiayaan ijarah, dimana terjadi pertukaran asset yang dilakukan oleh pihak yang memiliki asset dan pihak yang menggunakan asset tersebut. Ijarah ini merupakan pemindahan hak guna aset tanpa adanya pemindahan kepemilikan seperti transaksi jual beli (Karim, 2010).

Hasil penelitian ini menunjukkan adanya perbedaan yang signifikan pembiayaan ijarah sebelum dan selama pandemi covid-19, dimana hasil penelitian menunjukkan penurunan pembiayaan ijarah. Hal ini dapat dimaklumi karena situasi ekonomi masyarakat yang belum pasti, sehingga hal ini dapat berdampak pada tingkat profitabilitas bank Syariah. Hal ini mungkin sesuai dengan prediksi pada periode 2021 yang mengalami penurunan tingkat laba yang diperoleh (Afkar \& Fauziyah, 2021). Meskipun demikian bank syariah diharapkan tetap mematuhi aturan Syariah dalam menjalankan usahanya agar tidak menurunkan tingkat kepercayaan nasabah pada produk-produk Syariah (Susilo \& Anam, 2018).

\section{KESIMPULAN}

Pembiayaan syariah yang dilakukan dengan akad murabahah, istishna', dan ijarah sebelum dan selama pandemi covid-19 menunjukkan perbedaan. Pembiayaan murabahah dan istishna' menunjukkan peningkatan selama pandemi covid-19 dibandingkan dengan sebelum terjadi pandemi. Hal ini mmenunjukkan bahwa selama terjadinya pandemi covid-19, masyarakat dapat melakukan transaksi jualbeli secara tangguhan melalui pembiayaan syariah dan juga bank Syariah mampu menyalurkan dana untuk jenis pembiayaan jual-beli. Selain itu kondisi tersebut menunjukkan bahwa masyarakat di Indonesia terutama yang menjadi nasabah bank syariah cenderung melakukan transaksi yang bukan kebutuhan pokok melainkan kebutuhan lainnya. Sedangkan pada pembiayaan ijarah selama pandemi covid-19 terjadi penurunan jumlah rata-rata pembiayaan yang diberikan kepada nasabah. Artinya kemampuan bank syariah menurun dari pembiayaan ijarah, dengan kata lain masyarakat tidak tertarik melakukan transaksi jenis pembiayaan sewa selama pandemi covid-19.

\section{UCAPAN TERIMA KASIH}

Terima kasih kepada LPPM Universitas PGRI Adi Buana Surabaya yang telah memberikan kontribusi pendanaan penelitian, dan terima kasih kepada Fakultas Ekonomi dan Bisnis yang telah memberikan ijin penelitian.

\section{REFERENSI}

Afkar, T. (2015a). Analisis Daya Tahan Perbankan Syariah Dalam Krisis Keuangan Global. Disertasi.

Afkar, T. (2015b). Financing Mechanism of Islamic Banking. International Journal of Social Sciences, 32(1), 1-13.

Afkar, T. (2018). Influence Analysis Of Non Performing Financing by Profit-Loss Sharing Financing Contract To The Profitability Of Islamic Commercial Bank In Indonesia. AKRUAL: Jurnal Akuntansi, 10(1), 1-14. https://doi.org/10.26740/jaj.v10n1.p1-14

Afkar, T., \& Fauziyah. (2021). Predictions And Trends Profitability For Islamic Commercial Banks In Indonesia During The Covid-19. International Journal of Economics, Business, and Accounting Research (IJEBAR), 1(1), 188196.

https://doi.org/http://dx.doi.org/10.29040/ijebar. v5i1.2232

Alfie, A. A., \& Khanifah, M. (2018). Pembiayaan Natural Certainty Contract (Ncc) Dan Pembiayaan Natural Uncertainty Contract (Nuc) Pada Profitabilitas Bank Umum Syariah. Iqtisad, $5(2)$, 68-70. https://doi.org/10.31942/iq.v5i2.2550

Arianto, B. (2021). Dampak Pandemi COVID-19 terhadap Perekonomian Dunia. Jurnal Ekonomi Perjuangan, 2(2),

212-224. https://doi.org/10.36423/jumper.v2i2.665

Ascarya, \& Yumanita, D. (2008). Measuring the competitiveness of Islamic Banking in Indonesia dual banking system. TAZKIA Islamic Finance \& Business Review, 3(2), 72-89. 


\section{Jurnal Ilmiah Ekonomi Islam, 7(02), 2021, 907}

Eprianti, N., \& Adhita, O. (2017). Pengaruh Pendapatan Ijarah Terhadap Profitabilitas. Amwaluna: Jurnal Ekonomi Dan Keuangan Syariah, 1(1), 19-33. https://doi.org/10.29313/amwaluna.v1i1.1994

Hadiwardoyo, W. (2020). Kerugian Ekonomi Nasional Akibat Pandemi Covid-19. Baskara: Journal of Business and Entrepreneurship, 2(2), 83-92. https://doi.org/10.24853/baskara.2.2.8392

Hadiyan, N., Azman, N., Masron, T. A., \& Ibrahim, H. (2021). The Significance Of Islamic Social Finance In Stabilising Income For MicroEntrepreneurs During The Covid-19 Outbreak. Economics and Business Solutions Journal, 7(1), 115-136.

https://doi.org/http://dx.doi.org/10.26623/ebsj.v $2 \mathrm{i} 1.939$

Hanoatubun, S. (2020). Dampak Covid - 19 Terhadap Perekonomian Indonesia. EduPsyCouns: Journal of Education, Psychology and Counseling, 2(2), 146-153.

Hasyim, L. T. U. (2016). Peran Perbankan Syariah Terhadap Pertumbuhan Ekonomi Sektor Riil Di Indonesia. Akrual, 8(7), 11-27.

Herlyanto, F. D., \& Oktavendi, T. W. (2019). Meretas Kinerja Maqashid Syariah Pada Bank Umum Syariah Indonesia. El Muhasaba: Jurnal $\begin{array}{lll}\text { Akuntansi, } & \text { 10(1), }\end{array}$ https://doi.org/10.18860/em.v10i1.5929

Iskandar, R. (2016). Kontribusi dan Pertumbuhan Pembiayaan Bank Syariah Di Indonesia Berdasarkan Jenis Akad Periode Tahun 20082013. Maqdis: Jurnal Kajian Ekonomi Islam, $1(2)$, 237-248. https://doi.org/http://dx.doi.org/10.15548/maqdi s.v1i2.48

Karim, A. A. (2010). Perbankan Islam Analisis Fiqih dan Keuangan. Jakarta: PT. Raja Grafindo Persada.

Nabhan, F. (2010). Profit and Loss Sharing: Solusi Ekonomi Islam Menghadapi Globalisasi Ekonomi. Muqtasid: Jurnal Ekonomi Dan Perbankan Syariah, 1(2), 279. https://doi.org/10.18326/muqtasid.v1i2.279-301
Nurhayati, S., \& Wasilah. (2015). Akuntansi Syariah Di Indonesia. Jakarta : Selemba Empat.

Rohmah, S. N. (2020). Adakah Peluang Bisnis di Tengah Kelesuan Perekonomian Akibat Pandemi Coronavirus Covid-19? 'ADALAH; Buletin Hukum \& Keadilan, 4(1), 63-74. https://doi.org/https://doi.org/10.15408/adalah.v $4 \mathrm{i} 1.15448$

Rusydiana, A., \& Sanrego, Y. D. (2018). Measuring the Performance of Islamic Banking in Indonesia: an Application of Maslahah-Efficiency Quadrant (Meq). Journal of Islamic Monetary Economics and Finance, 3, 103-130. https://doi.org/10.21098/jimf.v3i0.909

Said, S., Sofyan, A. S., \& Amiruddin, A. M. A. (2019). Mashlaha in Financing Risk Measurement in Sharia Financing Institutions. Iqtishadia, 12(2), 240.

https://doi.org/10.21043/iqtishadia.v12i2.4992

Santoso, H., \& Anik, A. (2017). Analisis Pembiayaan Ijarah Pada Perbankan Syariah. Jurnal Ilmiah Ekonomi Islam, 1(02), 106-116. https://doi.org/10.29040/jiei.v1i02.33

Sari, D. W., \& Anshori, M. Y. (2018). Pengaruh Pembiayaan Murabahah, Istishna, Mudharabah, Dan Musyarakah Terhadap Profitabilitas (Studi Pada Bank Syariah Di Indonesia Periode Maret 2015 - Agustus 2016). Accounting and Management Journal, 1(1), 1-8. https://doi.org/10.33086/amj.v1i1.68

Susilo, E., \& Anam, A. K. (2018). Sharia Complience Akad Berbasis Natural Uncertainty Contract (NUC) Lembaga Keuangan Mikro Syariah Di Kabupaten Jepara. Al-Uqud: Journal of Islamic Economics, 2(1), 20-37. https://doi.org/10.26740/al-uqud.v2n1.p20-37

Tubastuvi, N. (2018). The Role of Profit-and-Loss Sharing Contracts in Strenghtening Financing Access of Small Medium Enterprise's (SME's): The Case of Indonesia. Advanced Science Letters, 24(1), 129-132. https://doi.org/10.1166/asl.2018.11938 